\title{
Anticardiolipin antibodies (ACA) directed not to cardiolipin but to a plasma protein cofactor
}

Citation for published version (APA):

Galli, M., Barbui, T., Comfurius, P., Maassen, C., Hemker, H. C., Zwaal, R. F. A., Bevers, E. M., de Baets, M. H., \& van Breda- Vriesman, P. J. C. (1990). Anticardiolipin antibodies (ACA) directed not to cardiolipin but to a plasma protein cofactor. Lancet, 335(8705), 1544-1547. https://doi.org/10.1016/01406736(90)91374-J

Document status and date:

Published: 01/01/1990

DOI:

10.1016/0140-6736(90)91374-J

Document Version:

Publisher's PDF, also known as Version of record

\section{Please check the document version of this publication:}

- A submitted manuscript is the version of the article upon submission and before peer-review. There can be important differences between the submitted version and the official published version of record. People interested in the research are advised to contact the author for the final version of the publication, or visit the DOI to the publisher's website.

- The final author version and the galley proof are versions of the publication after peer review.

- The final published version features the final layout of the paper including the volume, issue and page numbers.

Link to publication

\footnotetext{
General rights Owners
rights.

- You may freely distribute the URL identifying the publication in the public portal. please follow below link for the End User Agreement:

www.umlib.nl/taverne-license

Take down policy

If you believe that this document breaches copyright please contact us at:

repository@maastrichtuniversity.nl

providing details and we will investigate your claim.
}

Copyright and moral rights for the publications made accessible in the public portal are retained by the authors and/or other copyright owners and it is a condition of accessing publications that users recognise and abide by the legal requirements associated with these

- Users may download and print one copy of any publication from the public portal for the purpose of private study or research.

- You may not further distribute the material or use it for any profit-making activity or commercial gain

If the publication is distributed under the terms of Article $25 \mathrm{fa}$ of the Dutch Copyright Act, indicated by the "Taverne" license above, 
9. Klinkhoff AV, Thompson CR, Reid GD, Tomlinson CW. M-mode and two-dimensional echocardiographic abnormalities in systemic lupus erythematosus. FAMA 1985; 253: 3273-77.

10. Doherty NE, Feldman G, Maurer G, Siegel RJ. Echocardiographic findings in systemic lupus erythematosus. Am f Cardiol 1988; 61: 1144.

11. Tan EM, Cohen AS, Fries J, et al. The 1982 revised criteria for classification of SLE. Arthritis Rheum 1982; 25: 1271-72.

12. Committee on prognosis studies on SLE: An activity index. Arthritis Rheum 1986; 29 (suppl): 93.

13. Gharavi AE, Harris EN, Asherson RA, Hughes GRV. Anticardiolipin antibodies: isotype distribution and phospholipid specificity. Ann Rheum Dis 1987; 46: 1-6.

14. Harris EN, Gharavi AE, Patel SP, Hughes GRV. Evaluation of the anti-cardiolipin antibody test: report of an international workshop held 4 April 1986. Clin Exp Immunol 1987; 69: 215-22.

15. Exner T, Rickard KA, Kronenberg H. Studies on phospholipids in the action of a lupus coagulation inhibitor. Pathology 1975; 7: 319-28.

16. Libman E, Sacks B. A hitherto undescribed form of valvular and mural endocarditis. Arch Intern Med 1924; 33: 701-37.

17. Galve E, Candell-Riera J, Pigrau C. Permanyer-Miralda G, Garcia del Castillo H, Soler-Soler J. Prevalence, morphologic types, and evolution of cardiac valvular disease in systemic lupus erythematosus. $N \mathrm{Engl} F$ Med 1988; 319: 817-23.

18. Doherty NE, Siegel RJ. Cardiovascular manifestations of systemic lupus erythematosus. Am Heart f 1985; 110: 1257-65.

19. Mandell BF. Cardiovascular involvement in systemic lupus erythematosus. Semin Arthritis Rheum 1987; 17: 126-41.

20. Straaton KV, Chatham WW, Reveille JD, Koopman WJ, Smith SH. Clinically significant valvular heart disease in systemic lupus erythematosus. $A m \mathcal{F} \mathrm{Med}$ 1988; 85: 645-50.
21. Benotti JR, Sataline LR, Sloss LJ, Cohn LH. Aortic and mitral insufficiency complicating fulminant systemic lupus erythematosus. Chest 1984; 86: $140-43$.

22. Paget SA, Bulkley BH, Grauer LE, Seningen R. Mitral valve disease of systemic lupus erythematosus. A cause of severe congestive heart failure reversed by valve replacement. $A m \mathcal{F} \mathrm{Med} 1975$; 59: 134-39.

23. Chartash E, Lans DM, Paget SA, Qamar T, Lockshin MD. Aortic insufficiency and mitral regurgitation in patients with systemic lupus erythematosus and the antiphospholipid syndrome. Am 7 Med 1989; 86: 407-12.

24. Khamashta MA, Gil A, Asherson RA, Vázquez JJ, Hughes GRV. Antiphospholipid antibodies, valvular heart disease, and systemic lupus erythematosus. Am F Med 1989; 86: 633-34.

25. Crozier I, Li E, Milne $M$, Nicholls MG. Valvular heart disease in systemic lupus erythematosus. $N$ Engl f Med 1989; 320: 739-40.

26. Chambers JB, Monaghan MJ, Jackson G. Echocardiography, Information on morphology and function. $\mathrm{Br}$ Med $\mathcal{J}$ 1988; 297: 1071-76.

27. Harris EN, Chan JKH, Asherson RA, Aber VR, Gharavi AE, Hughes GRV. Thrombosis, recurrent fetal loss, and thrombocytopenia. Predictive value of the anticardiolipin antibody test. Arch Intern Med 1986; 146: 2153-56.

28. Lockshin $\mathrm{MD}$, Druzin $\mathrm{ML}$, Goei $\mathrm{S}$, et al. Antibody to cardiolipin as a predictor of fetal distress or death in pregnant patients with systemic lupus erythematosus. $N$ Engl 7 Med 1985; 313: 152-56.

29. Alarcón-Segovia D, Deleze M, Oria C, et al. Antiphospholipid antibodies and the antiphospholipid syndrome in systemic lupus erythematosus. A prospective analysis of 500 consecutive patients. Medicine (Baltimore) 1989; 68: 353-65.

30. Shapiro RF, Gamble CN, Wiesner KB, et al. Immunopathogenesis of Libman-Sacks endocarditis. Ann Rheum Dis 1977; 36: 508-16.

\title{
Anticardiolipin antibodies (ACA) directed not to cardiolipin but to a plasma protein cofactor
}

\author{
M. Galli P. Comfurius C. MAASSEN H. C. HeMKeR \\ M. H. DE BAETS P. J. C. VAN BREDA-VRIESMAN T. BARBUI \\ R. F. A. ZWAAL $\quad$ E. M. BEVERS
}

The binding of affinity-purified anticardiolipin antibodies (ACA) to liposomes that contained cardiolipin or phosphatidylserine was investigated. ACA bound to these liposomes only in the presence of plasma or serum, which indicated a requirement for a plasma component. This component-referred to as aca-cofactor-was purified; its activity to support ACA binding to liposomes that contained cardiolipin was not destroyed by heat $\left(10 \mathrm{~min}\right.$ at $\left.90^{\circ} \mathrm{C}\right)$, but was greatly diminished on incubation with trypsin. aca-cofactor bound liposomes that contained negatively charged phospholipid but had no affinity for liposomes that contained neutral phospholipid (eg, phosphatidylcholine); this binding was independent of calcium ions. aca-cofactor was essential for ACA to bind to liposomes that contained cardiolipin or phosphatidylserine and, when coated on a microtitre plate in the absence of any phospholipid, aca-cofactor was an apparent antigen for ACA in an enzyme-linked immunosorbent assay. aca-cofactor is a single chain polypeptide with an apparent molecular weight of $50 \mathrm{kD}$ (non-re- duced), which increases to $70 \mathrm{kD}$ upon reduction, and its properties closely resemble those of $\beta_{2}$-glycoprotein I (apolipoprotein $\mathbf{H}$ ).

Lancet 1990; 335: 1544-47.

\section{Introduction}

Anticardiolipin antibodies (ACA) and lupus anticoagulants (L.AC) are closely related autoantibodies, which may be found in the plasma of patients with systemic lupus erythematosus (SLE), other immunological, neoplastic, or infective disorders, and apparently normal people with no evidence of underlying disease. ${ }^{1}$ Some $30 \%$ of people who

ADDRESSES: Department of Haematology, Ospedali Riuniti, Bergamo, Italy (M Galli, MD, Prof T. Barbui, MD); Department of Biochemistry, Cardiovascular Research Institute Maastricht, University of Limburg, Netherlands ( $P$. Comfurius, $P h D, C$ Maassen, BSc, Prof H. C. Hemker, MD, Prof R. F. A Zwaal, PhD, E M. Bevers, PhD); and Department of Immunology, University of Limburg, Maastricht, Netherlands $(M . H$. de Baets, $M D$, Prof P. J. C. van Breda-Vriesman, MD). Correspondence to Dr E. M. Bevers Department of Biochemistry, University of Limburg, PO Box 616, 6200 MD Maastricht, Netherlands. 
have these antibodies suffer from arterial or venous thrombosis, thrombocytopenia, and repeated abortions. ${ }^{1}$ ACA and LAC are detected because they react with negatively-charged phospholipids (eg, phosphatidic acid, cardiolipin, phosphatidylserine, and phosphatidylinositol) in immunoassays ${ }^{2,3}$ and because they prolong phospholipiddependent clotting tests in vitro. ${ }^{4}$

In 1959, Loeliger ${ }^{5}$ observed that some plasma samples showed enhanced LAC activity when mixed with normal plasma; the concept of LAC cofactor was introduced, and prothrombin was suggested to represent this cofactor. ${ }^{5}$ In 1965, LAC cofactor was localised in the gammaglobulin fraction of both normal and LAC plasma. ${ }^{6}$ Rivard et $\mathrm{al}^{7}$ showed that LAC cofactor was neither prothrombin nor a gammaglobulin but a different molecule with an apparent molecular weight of $200 \mathrm{kD}^{7}$-although it has also been suggested that the cofactor is a laboratory artifact. ${ }^{8}$ We have purified and characterised a protein, termed aca-cofactor, which is found in normal plasma, and is required for the expression of ACA activity.

\section{Materials and methods}

We studied plasma from 2 men found to be seropositive for both ACA and LAC on routine investigation by enzyme-linked immunoassays (ELISAs). One patient, aged 39, had had repeated peripheral thrombosis; the other, aged 51, had had recurrent thrombosis of cerebral and renal arterioles. Neither had any other feature to suggest a diagnosis of SLE. ${ }^{9}$ ACA were purified by a modification of the method described by Pengo et al. ${ }^{10}$ Briefly, a mixture of cardiolipin, phosphatidylcholine, and cholesterol (molar ratio 2.5:10:4, respectively; all from Sigma, St Louis, Missouri, USA) in ethanol was dried under a stream of nitrogen. The lipids were resuspended directly in the plasma of the patients to a final cardiolipin concentration of $3 \mathrm{mg} / \mathrm{ml}$. After incubation at $37^{\circ} \mathrm{C}$ for $1 \mathrm{~h}$ the mixture was diluted 1:4 in "tris"-buffered saline (TBS; 0.05 $\mathrm{mol} / \mathrm{l} \mathrm{tris}, 0 \cdot 1 \mathrm{~mol} / 1 \mathrm{NaCl}, \mathrm{pH} 7 \cdot 4)$ and centrifuged at $20000 \mathrm{~g}$ for 15 $\min$ at $10^{\circ} \mathrm{C}$. The precipitate was washed 3 times with TBS and the liposomal pellet was dissolved in a $2 \%(w / v)$ solution of $n$-octyl- $\beta$ D-glucopyranoside (Sigma) in TBS so that the final concentration of cardiolipin was $3 \mathrm{mg} / \mathrm{ml}$. This mixture was applied to a column of protein A-'sepharose CL 4B' (Pharmacia Fine, Uppsala, Sweden). After extensive washing with $2 \%$ octylglucoside to remove the lipids, followed by washing with TBS, the bound IgG was eluted with $1 \mathrm{~mol} / \mathrm{l}$ acetic acid, and the eluates were immediately neutralised by $3 \mathrm{~mol} / \mathrm{l}$ "tris". Fractions that contained IgG were pooled and dialysed against TBS before they were tested for ACA content.

The ELISA for ACA essentially followed the procedure of Loizou et al. ${ }^{3}$ Briefly, microtitre plates were coated with cardiolipin $(30 \mu \mathrm{lof}$ a $50 \mu \mathrm{g} / \mathrm{ml}$ solution of cardiolipin in ethanol per well). After evaporation of the solvent, followed by washing with PBS, non-specific binding sites were blocked with $10 \%$ bovine serum albumin (Sigma) in PBS for $1 \mathrm{~h}$. Samples that contained ACA were diluted in $10 \%$ bovine serum in PBS and subsequently applied to the wells. The amount of ACA bound was assessed by incubation with peroxidase-conjugated goat anti-human IgG. After reaction of peroxidase with chromogenic substrate (tetramethylbenzidine) the optical density at $450 \mathrm{~nm}$ (OD 450) was measured.

ACA BINDING TO LIPOSOMES IN PRESENCE OF PLASMA OR PURIFIED ACA-COFACTOR

\begin{tabular}{l|c|c|c}
\hline $\begin{array}{c}\text { Liposome composition } \\
\text { (molar ratios) }\end{array}$ & Control (TBS) & Plasma & aca-cofactor \\
\hline CL:PC:Chol (2:5:10:4) & $4 \%$ & $96 \%$ & $94 \%$ \\
PS:PC:Chol (5:10:4) & $2 \%$ & $89 \%$ & $93 \%$ \\
PC:Chol (15:4) & $0 \%$ & $0 \%$ & $2 \%$
\end{tabular}

$\mathrm{CL}=$ cardiolipın; $\mathrm{PC}=$ phosphatidylcholıne; $\mathrm{Chol}=$ cholesterol, $\mathrm{PS}=$ phosphatıdylserine
To determine binding affinity to liposomes, $25 \mu$ ACA were mixed with $50 \mu \mathrm{l}$ cardiolipin:phosphatidylcholine:cholesterol (molar ratio 2.5:10:4) liposomes in the presence of $125 \mu \mathrm{l}$ plasma, TBS, or other test materials. Final concentrations were $125 \mu \mathrm{g} / \mathrm{ml}$ and $750 \mu \mathrm{g} / \mathrm{ml}$ for ACA and cardiolipin, respectively; aca-cofactor was used at a final concentration of $300 \mu \mathrm{g} / \mathrm{ml}$. After $30 \mathrm{~min}$ incubation at $37^{\circ} \mathrm{C}$ mixtures were centrifuged at $100000 \mathrm{~g}$ for 15 min and supernatants were evaluated for residual ACA activity by the standard ELISA described above. Data are calculated according to the formula:

$$
\frac{\mathrm{ACA}_{\text {total }}-\mathrm{ACA} \mathrm{A}_{\text {supernatant }}}{A C A_{\text {total }}} \times 100 \%
$$

In some experiments liposomes were used in which cardiolipin was replaced by phosphatidylserine at a molar ratio for phosphatidylserine:phosphatidylcholine:cholesterol of 5:10:4 to correct for the difference in nett charge between cardiolipin and phosphatidylserine or by phosphatidylcholine at a molar ratio for phosphatidylcholine:cholesterol of 15:4.

aca-cofactor was purified from plasma by ammonium sulphate precipitation $(50 \%-90 \%$ saturation) followed by ion-exchange chromatography on 'QAE-Sephadex' in $50 \mathrm{mmol} / 1$ "tris" buffer at $\mathrm{pH} 7 \cdot 4$. The column was eluted by a salt-gradient and aca-cofactor activity was recovered at $100 \mathrm{mmol} / \mathrm{l} \mathrm{NaCl}$. Sodium dodecylsulphate polyacrylamide gel electrophoresis (SDS-PAGE) was done on a $7.5 \%$ polyacrylamide gel with a $4 \%$ polyacrylamide stacking gel; after electrophoresis the gel was stained with coomassie brilliant blue. Protein content of samples was assayed according to Sedmak and Grossberg. ${ }^{11}$

\section{Results and discussion}

Affinity-purified ACA from the plasma of both patients reacted strongly with cardiolipin in a lipid-based ELISA. Binding was little changed by substitution of cardiolipin by phosphatidylserine, whereas binding of affinity-purified ACA was abolished with phosphatidylcholine-coated wells (data not shown). In direct binding experiments, in which ACA were incubated with liposomes composed of a mixture of cardiolipin, phosphatidylcholine, and cholesterol in TBS, the $100000 \mathrm{~g}$ supernatant of this incubation still contained $100 \%$ ACA activity - which indicated no ACA binding to liposomes. Replacement of TBS by normal plasma reduced ACA activity in the supernatant to less than $5 \%$ (table),

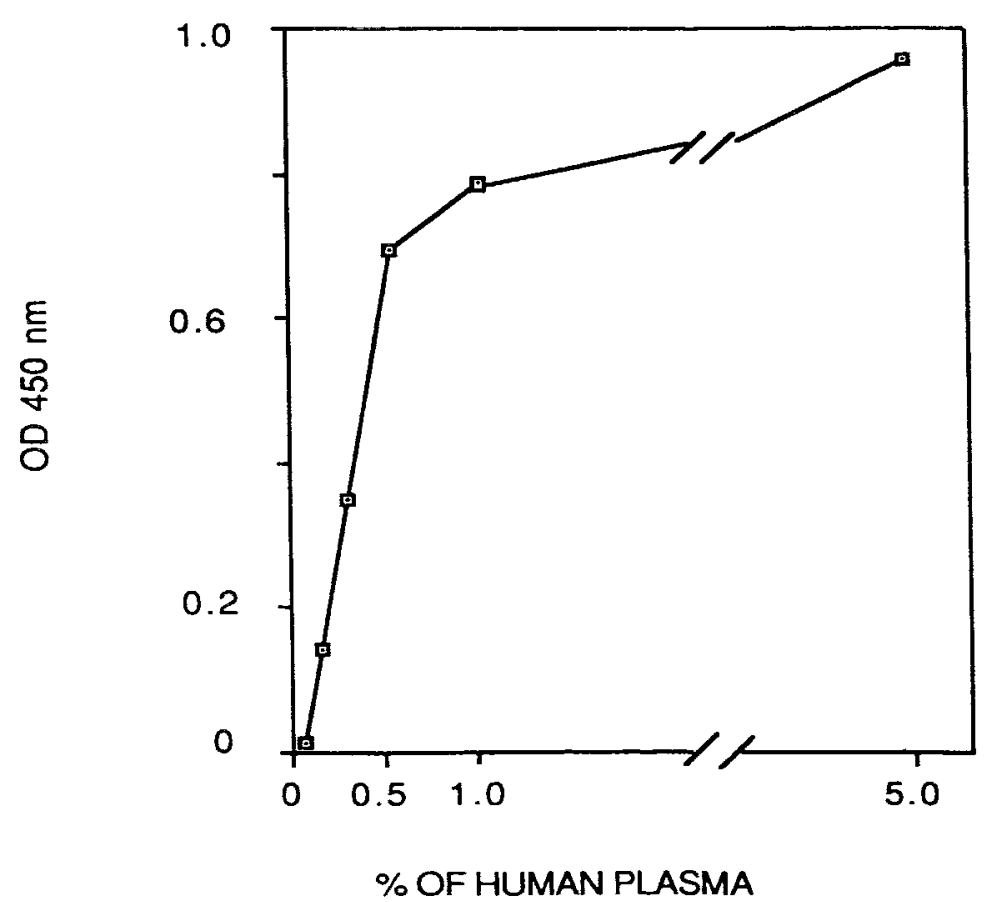

Fig 1-ACA binding to immobilised cardiolipin at different concentrations of normal plasma. 


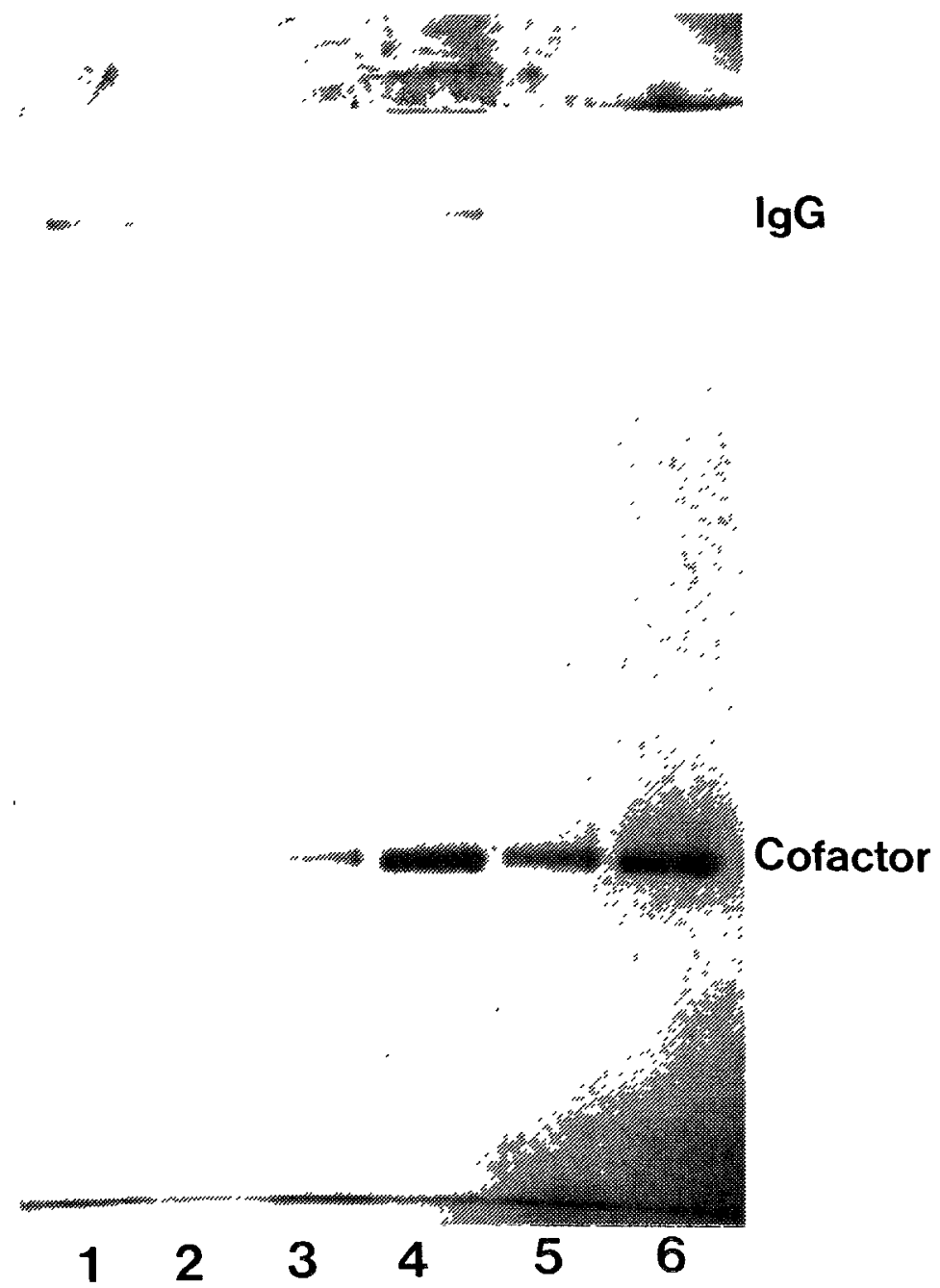

Fig 2-Binding of ACA and/or aca-cofactor to liposomes that contain cardiolipin.

Lanes 1 \& 2: ACA with liposomes; lanes $3 \& 4$ : ACA and aca-cofactor with liposomes; lanes 5 \& 6: aca-cofactor with liposomes.

Lanes 1,3, and 5 represent proteins in the supernatant, lanes 2, 4, and 6 represent proteins in the liposomal pellet

and a similar result was obtained when phosphatidylserine was substituted for cardiolipin. No ACA binding was found to liposomes composed of phosphatidylcholine and cholesterol. These findings indicate that a plasma component is involved in the binding of ACA to liposomes that contain negatively charged phospholipids, as suggested

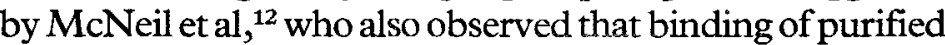
antiphospholipid antibodies to immobilised phospholipid required the presence of plasma.

In the standard ELISA for ACA, different dilutions of the antibody-containing samples are routinely made in $10 \%$ bovine serum in TBS; the same medium is also used during the binding-step of ACA to the cardiolipin-coated wells of the microtitre plates. We found that bovine serum could be replaced by bovine plasma, human serum, or human plasma, but not by purified bovine or human serum albumin. To further investigate the role of plasma in ACA binding to cardiolipin, the standard ELISA was modified. Instead of dilution in $10 \%$ bovine serum, constant amounts of ACA were mixed with dilutions of normal pooled plasma and applied to the well. Microtitre plates were further processed as described for the standard ELISA. Fig 1 shows the OD 450 as a function of the plasma concentration: a linear correlation between OD and plasma concentrations is observed from 0 to $0.5 \%$, where a plateau is reached; similar findings were obtained with human serum and bovine plasma or serum. Thus a plasma component

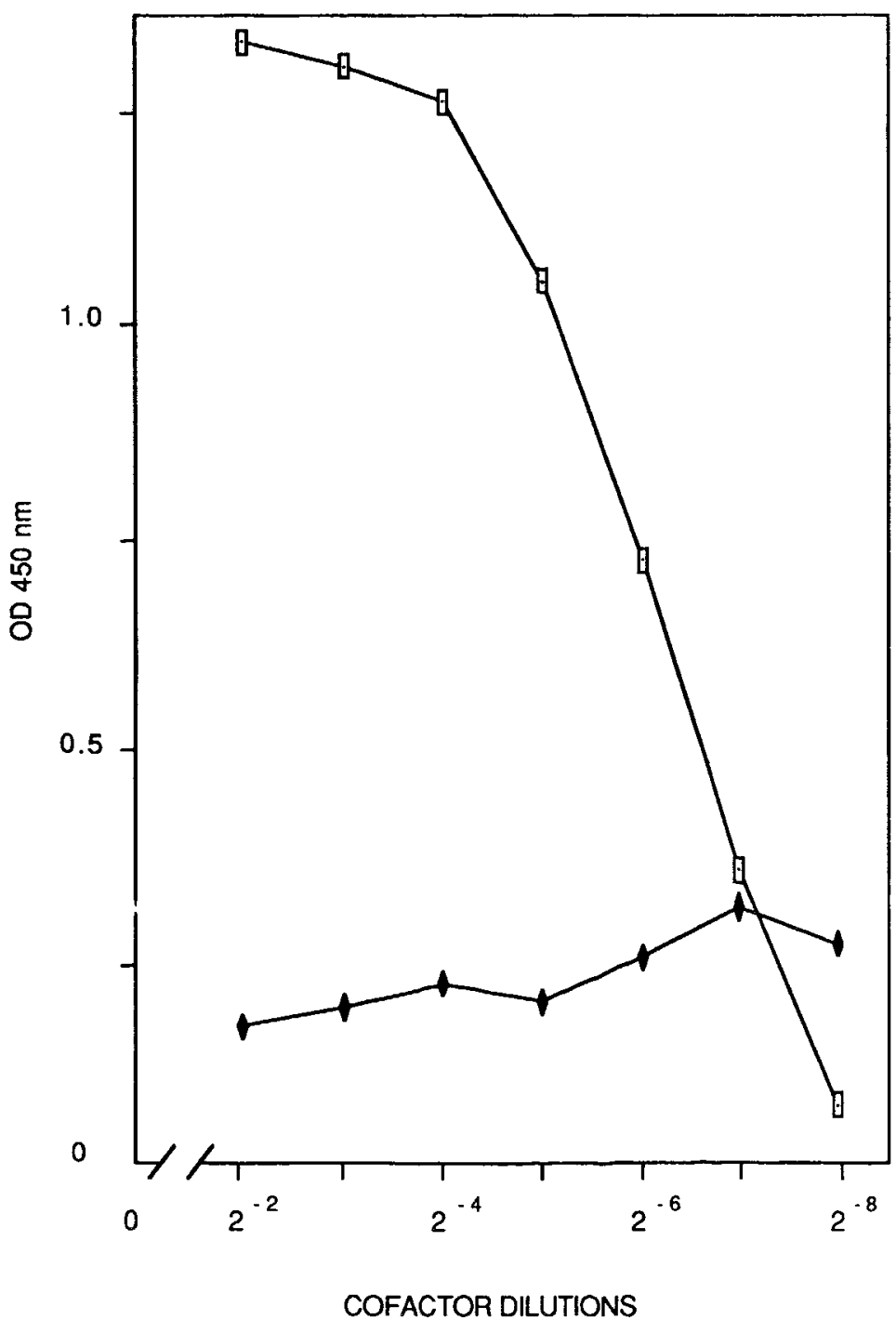

Fig 3-lgG binding to microtitre plates coated with acacofactor in absence of phospholipid.

$\exists=$ affinity purified anticardiolipin $\operatorname{lgG}(17 \mu \mathrm{g} / \mathrm{ml})$.

$\checkmark=$ normal (non-specific) $\operatorname{lgG}(133 \mu \mathrm{g} / \mathrm{ml})$.

Concentration of undiluted aca-cofactor was $300 \mu \mathrm{g} / \mathrm{ml}$.

is necessary for ACA binding to immobilised cardiolipin. This plasma component, termed aca-cofactor, can be detected and measured by this modified ELISA by comparison with a calibration curve as shown in fig 1 .

The final step in the purification of aca-cofactor involves heat treatment $\left(10 \mathrm{~min}\right.$ at $90^{\circ} \mathrm{C}$ ) followed by centrifugation to remove denatured protein material. No loss of acacofactor activity occurred in this step, but when the preparation obtained was incubated with trypsin, acacofactor became inactive. SDS-PAGE showed aca-cofactor to be a single-chain polypeptide with an apparent molecular weight of $50 \mathrm{kD}$ (non-reduced) which increased to $70 \mathrm{kD}$ upon reduction. The specific activity of the cofactor preparation was 350 times that of crude plasma; if $100 \%$ purity of this preparation was assumed the plasma concentration of aca-cofactor would be approximately 0.2 $\mathrm{mg} / \mathrm{ml}$.

Purified aca-cofactor was used to study the interaction of affinity-purified ACA with liposomes (see table). acacofactor can be substituted for plasma without loss of binding of ACA to liposomes that contained negativelycharged phospholipid. Both supernatant and pellet of the binding experiments with purified aca-cofactor and/or ACA were analysed by SDS-PAGE as shown in fig 2 for samples 
obtained after incubations with cardiolipin-containing liposomes; similar results are obtained with liposomes that contained phosphatidylserine. No binding of either of the proteins was observed with liposomes without negativelycharged lipids. Without cofactor, no IgG was detectable in the $100000 \mathrm{~g}$ pellet of the incubations (lanes 1,2 ); with cofactor, approximately $60-70 \%$ of the IgG co-sediments with the liposomes (lanes 3, 4). Incomplete binding of IgG was not due to a limiting amount of aca-cofactor and the unbound fraction of IgG in the $100000 \mathrm{~g}$ supernatant no longer contained any ACA activity, so the IgG fraction isolated from the plasma presumably contains antibodies other than ACA with non-specific binding to the liposomes used in the affinity purification procedure, or antibodies directed against other lipid-binding proteins in plasma.

Fig 2 shows that aca-cofactor also binds to liposomes that contain cardiolipin in the absence of $\operatorname{IgG}$ (lanes 5,6). Binding of aca-cofactor is not dependent on or inhibited by the presence of calcium ions, so it is unlikely that binding is mediated by $\gamma$-carboxyglutamic acid residues on the cofactor. We investigated the direct interaction between aca-cofactor and affinity-purified ACA in an ELISA in which the microtitre plates were coated with different amounts of cofactor. After coating, a fixed amount of ACA or normal IgG was applied to the wells in the absence of phospholipid. ACA binding was proportional to the amount of aca-cofactor in the wells (fig 3) and no binding was found with normal human IgG. Thus anticardiolipin antibodies of at least these two patients are not directed against cardiolipin but against a protein with a high affinity for negativelycharged phospholipid surfaces.

It is remarkable that the cofactor is not co-purified during the affinity purification of ACA via cardiolipin-containing liposomes. Two possible explanations might account for this: ACA only recognises aca-cofactor when bound to lipid or absorbed on a microtitre plate; or aca-cofactor undergoes structural modification upon addition of octylglucoside during ACA purification. Although aca-cofactor is present in normal human (and bovine) plasma in concentrations of up to $0.2 \mathrm{mg} / \mathrm{ml}$, its identity is still obscure. The heat stability and behaviour on SDS-PAGE (increase in apparent molecular weight upon reduction) suggest the presence of several disulphide bridges. Preliminary experiments with purified coagulation factors indicate that binding of aca-cofactor to negatively-charged phospholipid surfaces interferes with binding of the prothrombin activating complex factor Xa-factor $\mathrm{Va}$, leading to a diminished rate of thrombin formation. Thus ACA may be directed against a naturally circulating anticoagulant with high affinity towards negatively-charged phospholipid surfaces.

The high purity of the aca-cofactor allows analysis of aminoacid composition, which is under investigation. However the properties so far identified (molecular weight $50 \mathrm{kD}$ [non-reduced], $70 \mathrm{kD}$ [reduced with $5 \%$ $\beta$-mercaptoethanol]; estimated plasma concentration 200 $\mu \mathrm{g} / \mathrm{ml}$; heat stability; calcium-independent binding to anionic phospholipids; support of ACA binding to anionic phospholipids; and inhibition of phospholipid-dependent coagulation reactions) are very similar to those of $\beta_{2}$-glycoprotein I (apolipoprotein $\mathbf{H}$ ), the anticoagulant properties of which we have previously described. ${ }^{13}$

M. G. was supported by grant EC 87-022514 from the European Community. We thank Dr W. Grave for plasma samples from one of the patients and Mrs M. Molenaar-van de Voort for secretarial assistance.

\section{REFERENCES}

1. Lechner $K$. Lupus anticoagulants and thrombosis. In: Verstraete $\mathbf{M}$, Vermylen J, Lijnen HR, Arnout J, eds. Thrombosis and haemostasis 1987. Leuven: International Society on Thrombosis and Haemostasis and Leuven University Press, 1987: 525-47.

2. Harris EN, Gharavi AE, Boey ML, et al. Anticardiolipin antibodies: detection by radioimmunoassay and association with thrombosis in systemic lupus erythematosus. Lancet 1983; ii: 1211-14.

3. Loizou S, McCrea JD, Rudge AC, et al. Measurement of anti-cardiolipin antibodies by an enzyme-linked immunosorbent assay: standardization and quantitation of results. Clin Exp Immumol 1985; 62: 738-44.

4. Green D, Hougie C, Kazmier FJ, Report of the working party on acquired inhibitors of coagulation: studies of "lupus" anticoagulant. Thromb Haemost 1983; 49: $144-46$.

5. Loeliger A. Prothrombin as co-factor of the circulating anticoagulant in systemic lupus erythematosus? Thromb Diath Haemorrh 1959; 3: 237-56.

6. Yin $\mathrm{ET}$, Gaston LW. Purification and kinetic studies on a circulating anticoagulant in a suspected case of lupus erythematosus. Thromb Diath Haemorrh 1965; 14: 88-115.

7. Rivard GE, Schiffman S, Rapaport SI, Cofactor of the "lupus anticoagulant'. Thromb Diath Haemorrh 1974; 32: 554-63.

8. Shapiro SS, Thiagarajan P. Lupus anticoagulant. Prog Hemostas Thromb 1982; 6: 263-82.

9. Tan EM, Cohen AS, Fries JF, et al. The 1982 revised criteria for the classification of systemic lupus erythematosus. Arthritis Rheum 1982; 25: $1271-76$.

10. Pengo V, Hein MJ, Thiagarajan $P$, Shapiro SS. Immunological specificity and mechanism of action of $\mathrm{IgG}$ lupus anticoagulants. Blood 1987; 70:69-76.

11. Sedmak JJ, Grossberg SE. A rapid, sensitive and versatile assay for protein using coomassie brilliant blue G 250. Anal Biochem 1977; 79: 544-52.

12. McNeil HP, Chesterman CN, Krilis SA. Anticardiolipin antibodies and lupus anticoagulants comprise antibody subgroups with different phospholipid binding characteristics. Br F Haematol 1989; 73: 506-13.

13. Nimpf J, Bevers EM, Bomans PHH, et al. Prothrombinase activity of human platelets is inhibited by $\beta_{2}$-glycoprotein I. Biochim Biophys Acta $1986 ; 884: 142-49$.

\section{From The Lancet}

\section{Medical examinations}

The qualified practitioners of the present day are all members of medical corporations. Are they to have anything to do with the management of those corporations? Are twenty-one, or any other number, of self-elected, irresponsible gentlemen in London, Dublin, or Edinburgh, to appropriate the public money, expend it as they please, dispose of the property, power, patronage, and interests of twenty or thirty thousand enlightened men scattered over the United Kingdom? Have the physicians, surgeons, general practitioners of the United Kingdom no fair claim to the franchise? Are they to be mocked for ever by the Councils of their own Institutions, and to be trampled under foot by the Poor-Law Commissioners, or by any other class of men, from the want of the energy and protection which a united, well-organised, representative corporation would give? Does any one mean to assert, that the present generation of practitioners is unworthy of a free constitution; that we do not understand our own interests and rights; or are so besotted as to be incapable of selecting representatives who would promote science, study the public good, and uphold the honour of the profession? Are we to sow all for the next generation, and to reap nothing? Are our successors to surpass us so immeasurably, because they undergo a uniform examination? Our faith in the qualifications of the present race of practitioners is great. They have become what they are, intelligent, efficient, high-minded, in spite of the worst examinations, and the worst means of education that were ever devised by the ingenuity or wickedness of man.

(8 August 1840) 